\title{
Selective Expression of the Immediate Early Gene c-jun in Axotomized Rat Medial Septal Neurons Is Not Related to Neuronal Degeneration
}

\author{
Carola A. Haas, Thomas Deller, Thomas Naumann, and Michael Frotscher \\ Institute of Anatomy, Univorsity of Froiburg, D 79001 Froiburg, Germany
}

In the present study, we use the anatomically well defined septohippocampal projection to study the molecular events involved in the reaction of neurons to axotomy. The expression of three immediate early genes (c-fos, c-jun, and jun B) was investigated in rat septohippocampal neurons after axotomy by bilateral fimbria-fornix transection (FFT). Moreover, the extent of retrograde degeneration in the septal complex was assessed by analyzing DNA fragmentation. In a postoperative time course analysis, a strong increase of c-jun immunoreactivity (IR) was observed in the nuclei of neurons in the medial septum/ diagonal band complex (MSDB) 2 and $6 \mathrm{~d}$ postaxotomy, which was followed by a decline after $12 \mathrm{~d}$ and 3 weeks, respectively. Nine weeks after FFT, c-jun IR had disappeared. The c-junpositive MS neurons were identified as former septohippocampal projection cells by double-labeling with the retrogradely transported tracer Fluoro-Gold injected into the hippocampus before axotomy. In line with the immunocytochemical data, there was a massive induction of $c$-jun mRNA in the axotomized MS neurons as visualized by in situ hybridization histochemistry. c-fos mRNA and c-fos or jun B IR were not detectable in either unoperated or lesioned medial septal neurons. Experiments using the TdT-mediated deoxyuridine triphosphate nick-end-labeling technique, designed to detect nuclear DNA fragmentation in degenerating neurons, complemented this study. During the postoperative time range studied, MS neurons did not exhibit DNA fragmentation. We conclude that MSDB neurons survive axotomy by FFT and display characteristic changes in gene expression.

Key words: septohippocampal projection; transcription factor; axotomy; retrograde degeneration; retrograde tracing; in situ hybridization
The anatomically well defined fimbria-fornix system, which connects the septal complex with the hippocampal formation, has been used often as a paradigm to study lesion effects on CNS neurons, because this fiber tract can be transected completely without affecting vital functions of the animal. The septohippocampal projection neurons display either cholinergic (Lewis and Shute, 1967; Houser et al., 1983; Amaral and Kurz, 1985; Bialowas and Frotscher, 1987) or GABAergic phenotype (Köhler et al., 1984; Freund and Antal, 1988). Their cell bodies are located in the medial septum/diagonal band complex (MSDB) and undergo retrograde changes in response to axotomy by fimbriafornix transection (FFT). Thus, there is a massive loss of immunocytochemically identified cholinergic and GABAergic medial septal neurons after FFT (Gage et al., 1986, 1988; Hefti, 1986; Williams et al., 1986; Armstrong et al., 1987; Kromer, 1987; Peterson et al., 1987; Frotscher, 1988; Naumann et al., 1994), which was interpreted as retrograde neuronal death of these cells (for review, see Gage et al., 1989). Recent studies, however, demonstrated that axotomized medial septal neurons may survive for long periods of time, as shown by prelabeling of these cells with the retrograde tracer Fluoro-Gold (FG) before axotomy and electron microscopy of the prelabeled and then axotomized neu-

\footnotetext{
Received Aug. 21, 1995; revised Nov. 14, 1995; accepted Nov. 29, 1995.

C.A.H. was supported by the Leibniz Program of the Deutsche Forschungsgemeinschaft. We thank $\mathrm{H}$. Banse and $\mathrm{M}$. Winter for excellent technical assistance, Dr. M. Kirsch for the preparation of newborn rat retinae, and Dr. H. Holländer for the protocol of the TUNEL procedure.

Correspondence should be addressed to Michael Frotscher, Institute of Anatomy, University of Freiburg, P.O. Box 111, D-79001 Freiburg, Germany.

Copyright (C) 1996 Society for Neuroscience $0270-6474 / 96 / 161894-10 \$ 05.00 / 0$
}

rons after varying survival periods (Peterson et al., 1990, 1992; Naumann et al., 1992b). Moreover, the axotomized cholinergic neurons regain their IR for choline acetyltransferase (ChAT) after 6 months postlesion, again indicating survival rather than cell death (Naumann et al., 1994). In line with these studies after axotomy, Sofroniew et al. $(1990,1993)$ and Plaschke el al. (1994) demonstrated that removal of hippocampal target tissue by excitotoxic lesions did not result in a massive loss of ChAT-positive neurons in the MSDB, despite disconnection from neurotrophinproducing target cells.

The pattern of gene expression of CNS neurons after axotomy is poorly understood; however, immediate early genes such as c-jun, c-fos, and jun B seem to be involved in lesion-induced neuronal events. The products of these genes function as transcription factors (Sheng and Greenberg, 1990; Morgan and Curran, 1991), which are differentially expressed after lesions of the CNS or peripheral nervous system (Jenkins and Hunt, 1991; Leah et al., 1991; Dragunow, 1992; Herdegen et al., 1992, 1993; Haas et al., 1993; Jenkins et al., 1993b; Koistinaho et al., 1993; Hüll and Bähr, 1994a,b; Brecht et al., 1995). Recent evidence suggests that c-jun expression in injured neurons is not merely a response to damage but rather is associated with the neuronal growth response (Jenkins et al., 1993a).

On the basis of the concept that medial septal neurons potentially survive axotomy and may regenerate axonal processes, we have investigated the expression of immediate early genes (c-jun, c-fos, and jun B) in the medial septal nucleus after FFT. In addition, we have studied these central axotomized neurons for DNA fragmentation, which is indicative of degenerating neurons 
in other lesion models (Berkelaar et al., 1994; Rabacchi et al., 1994; Nitatori et al., 1995).

\section{MATERIALS AND METHODS}

Animal surgery. Bilateral FFTs were performed as described by Naumann et al. (1992b). Briefly, adult male Sprague-Dawley rats (weighing 250 $300 \mathrm{gm}$ ) were deeply anesthetized with a mixture of ketamin, rompun, and ketavet $(2.5 \mathrm{ml} / \mathrm{kg}$ body weight, i.m. $)$ and placed in a stereotaxic apparatus. The skull was opened bilaterally $1 \mathrm{~mm}$ posterior to bregma, extending $5 \mathrm{~mm}$ on either side of the midline. Under visual control, the overlying cortical tissue was removed by aspiration to access the fimbriafornix, which was aspirated bilaterally. All surgery was performed in accordance with institutional guidelines for animal welfare. The animals were allowed to survive for $1 \mathrm{~d}(n=4), 2 \mathrm{~d}(n=4), 6 \mathrm{~d}(n=4), 8 \mathrm{~d}(n$ $=4), 12 \mathrm{~d}(n=2), 21 \mathrm{~d}(n=5)$, and 9 weeks $(n=3)$. Unoperated animals $(n=4)$ served as controls.

Retrograde prelabeling of medial septal neurons. The retrograde tracer Fluoro-Gold (FG; Fluorochrome, Englewood, $\mathrm{CO} ; 2.5 \%$ in $\mathrm{H}_{2} \mathrm{O}$ ) was stereotaxically injected into the right hippocampus of five adult male anesthetized (see above) rats, as described previously (five injections of $30 \mathrm{nl} \mathrm{FG}$ each into different septotemporal portions of the hippocampus; coordinates from bregma: AP 3.4, ML 2.2., DV -3.38; AP 3.8, ML 3.0, DV -3.6; AP 5.5, ML 3.8, DV -4.1; AP 6.1, ML 4.1, DV -4.74; AP 5.8, ML 4.7, DV -6.6) (Naumann et al., 1992a). The animals were returned to their home cages for $5 \mathrm{~d}$. Four of the FG-injected animals then received a unilateral FFT and were allowed to survive for another $6 \mathrm{~d}$.

Immunohistochemistry. Animals were anesthetized as described above and transcardially perfused for $3 \mathrm{~min}$ with $0.1 \mathrm{M} \mathrm{PBS,} \mathrm{pH} \mathrm{7.2,} \mathrm{followed} \mathrm{by}$ $4 \%$ paraformaldchyde buffercd with PBS for $20 \mathrm{~min}$. The brains werc removed from the skull and immersed in the same fixative for $2 \mathrm{~d}$. Tissue sections $(50 \mu \mathrm{m}$, coronal plane of the septal region and horizontal plane of the hippocampus) were cut on a vibratome and collected in PBS. For immunohistochemistry, a floating procedure was applied. Tissue sections were rinsed three times for $5 \mathrm{~min}$ in PBS and then pretreated for $30 \mathrm{~min}$ with a solution containing $10 \%$ normal goat serum (NGS), $0.25 \%$ Triton $\mathrm{X}-100$, and PBS. Sections were rinsed again with PBS two times for $5 \mathrm{~min}$ followed by incubation with the primary antibody diluted in $1 \%$ NGS, $0.1 \%$ Triton $\mathrm{X}-100$, and $0.01 \%$ sodium azide (normal horse serum was used for mouse monoclonal antibodies). The following antibodies were used in this study: rabbit polyclonal anti-c-jun/AP1, PC06 (Oncogene Science, Uniondale, NY), $100 \mu \mathrm{g} / \mathrm{ml}$, dilution 1:100; rabbit polyclonal anti-c-jun (636/3; gift from R. Bravo, Bristol-Meyers Squibb Pharmaceutical Research Institute, Princeton, NJ), dilution 1:25,000; rabbit polyclonal anti-c-fos, PC05 (Oncogene Science), $100 \mu \mathrm{g} / \mathrm{ml}$, dilution 1:100; rabbit polyclonal anti-jun $B$ (gift from $\mathrm{R}$. Bravo), dilution 1:4000; rabbit polyclonal anti-jun B (Biotechnology, Santa Cruz, CA), dilution 1:1000; and rat-mouse hybridoma anti-ChAT, type I (Boehringer Mannheim, Mannheim, Germany), dilution 1:9.

Incubation with the primary antibodies was performed at room temperature (RT) for $5 \mathrm{hr}$ and then for $12 \mathrm{hr}$ at $4^{\circ} \mathrm{C}$ on a rotating shaker. Thereafter, the sections were washed carefully in PBS and exposed to the secondary biotinylated goat anti-rabbit and horse anti-mouse antibodies (Vector Laboratories, Burlingame, CA), respectively, for $2 \mathrm{hr}$ at RT (diluted in PBS, 1:250). After washes in PBS, the tissue-bound antibodies were visualized using the Vectastain $\mathrm{ABC}$ Kit (Vector Laboratories) and reacted with $3,3^{\prime}$-diaminobenzidine (DAB) [(Sigma, Deisenhofen, Germany) $0.05 \%$ in PBS with $\left.0.002 \% \mathrm{I}_{2} \mathrm{O}_{2}\right]$. The development of the reaction product was monitored visually. As the last step, tissue sections were mounted on gelatin-coated slides, air-dried, dehydrated in graded ethanol, and coverslipped with permount. As a negative control, incubation with the primary antibody was omitted. No immunostaining occurred under these conditions.

Double-labeling $c$-jun/FG. The FG-injected and fimbria-fornixtransected animals were transcardially perfused, vibratome sections were prepared, and c-jun immunostaining was performed as described in detail above. Visualization was achieved by a DAB reaction with nickel intensification, which resulted in a dark brown nuclear reaction product. Thereafter, the sections were washed again in PBS and preincubated in $10 \%$ NGS for 30 min followed by incubation with a polyclonal antibody solution to FG (Biogenesis, Bournemouth, UK), diluted 1:4000, for $2 \mathrm{~d}$ at $4^{\circ} \mathrm{C}$. Next, after exposure to a biotinylated anti-rabbit IgC $(1: 250 ; 2 \mathrm{hr})$ and the $\mathrm{ABC}$ reagents (ABC-Elite, Vector Laboratories), the tissuebound peroxidase was visualized with $\mathrm{DAB}$ for $5 \mathrm{~min}$, which resulted in a brown cytoplasmic precipitate.

Acetylcholinesterase histochemistry. To assess the completeness of the
FFT, hippocampal sections of all experimental animals were processed for acetylcholinesterase (AChE) histochemistry according to Mesulam et al. (1987). Only those brains in which the typical AChE pattern in the fascia dentata and hippocampus proper was lost as a consequence of the FFT were included in the analysis.

TdT-mediated deoxyuridine triphosphate nick-end-labeling. The procedure of Gavrieli et al. (1992) was modified and adapted for vibratome sections. Animal perfusion and tissue fixation was performed as described for immunohistochemistry. Vibratome sections of $50 \mu \mathrm{m}$ were cut from scptal and hippocampal tissuc as described above and mounted on gelatin-coated slides for the TdT-mediated deoxyuridine triphosphate nick-end-labeling (TUNEL) procedure. Sections were rinsed with $0.1 \mathrm{M}$ PBS, pH 7.2, and treated for 15 min with $0.3 \%$ Triton $\mathrm{X}-100$ followed by a 5 min wash in PBS. Nuclei stripping was performed by incubation with $20 \mu \mathrm{g} / \mathrm{ml}$ proteinase $\mathrm{K}$ (Boehringer Mannheim) in $10 \mathrm{mM} \mathrm{Tris} / \mathrm{HCl}, \mathrm{pH}$ 8.0 , for $30 \mathrm{~min}$ at $\mathrm{RT}$, and then the sections were rinsed thoroughly four times in distilled $\mathrm{H}_{2} \mathrm{O}$ for $2 \mathrm{~min}$. Endogenous peroxidase was inactivated by covering the sections with $3 \% \mathrm{H}_{2} \mathrm{O}_{2}$ for $10 \mathrm{~min}$ at RT. Again, sections were rinsed in water, two times for $5 \mathrm{~min}$, and equilibrated for $10 \mathrm{~min}$ in terminal transferase buffer composed of $5 \mathrm{~mm}$ cobalt chloride, $25 \mathrm{~mm}$ Tris/ $\mathrm{HCl}, \mathrm{pH} 6.6,0.2 \mathrm{M}$ potassium cacodylate, and $0.25 \mathrm{mg} / \mathrm{ml} \mathrm{BSA}$ before the actual incubation with $0.3 \mathrm{U} / \mu$ l terminal deoxynucleotidyl transferase (Boehringer Mannheim) and biotinylated deoxyuridine triphosphate (dUTP), $40 \mathrm{pmol} / \mu \mathrm{l}$. The tailing reaclion was performed in a small volume $(10 \mu \mathrm{l} / \mathrm{section})$ under parafilm at $37^{\circ} \mathrm{C}$ for $60 \mathrm{~min}$ in a humid chamber. The reaction was stopped by transferring the tissue into a solution containing $300 \mathrm{~mm}$ sodium chloride and $30 \mathrm{~mm}$ sodium citrate for $15 \mathrm{~min}$ at RT. After two rinses in PBS, 5 min each, the sections were treated with $2 \%$ BSA in PBS followed by $0.3 \%$ Triton X-100 in PBS and subsequently processed with standard avidin-biotin-peroxidase (Vectastain $\mathrm{ABC}$ Kit, Vector Laboratories) to visualize the incorporated biotinylated dUTP.

In positive controls, a DNase I treatment was performed before incubation with terminal transferase. Tissue sections were digested with 1 $\mu \mathrm{g} / \mathrm{ml}$ DNase I (Sigma) for $15 \mathrm{~min}$ in a buffer containing $50 \mathrm{~mm} \mathrm{Tris} / \mathrm{IICl}$, $\mathrm{pH} 7.5,10 \mathrm{~mm} \mathrm{MgSO}{ }_{4}, 0.1 \mathrm{~mm}$ dithiothreitol, and $50 \mu \mathrm{g} / \mathrm{ml}$ BSA. After careful washes in distilled $\mathrm{H}_{2} \mathrm{O}$ (4 times for $2 \mathrm{~min}$ ), the tissue was processed further for TUNEL.

As an endogenous control for the detection of apoptotic cells, wholemounts of newborn rat retina were carried through the TUNEL procedure.

In situ hybridization histochemistry. In situ hybridization histochemistry with synthetic oligonucleotide probes was performed as described by Haas et al. (1993). In short, the oligonucleotide sequence was as follows: c-jun (45-mer) (antisense 5'-GCA ACT GCT GCG TTA GCA TGA GTT GGC $\Lambda$ CC C $\Lambda$ C TGT T $\Lambda \Lambda$ CGT GGT-3') homologous to the last 15 amino acids of the predicted c-jun protein (Angel et al., 1988). The sense oligonucleotide to this sequence was used as negative control.

The oligonucleotides were labeled by 3 '-end tailing using a 30:1 molar ratio of $\left[\alpha^{-3} \mathrm{P}\right] \mathrm{dATP}$ to oligonucleotide; $0.3 \mathrm{pmol}$ of oligonucleotide was tailed in the presence of $30 \mu \mathrm{Ci}$ of $\left[\alpha{ }^{33} \mathrm{P}\right] \mathrm{dATP}(3000 \mathrm{Ci} / \mathrm{mmol}$; DuPont NEN, Bad Homburg, Germany) with terminal deoxynucleotidyl transferase (Boehringer Mannheim) in a buffer containing $25 \mathrm{mM} \mathrm{Tris} / \mathrm{HCl}$, $\mathrm{pH} 6.5,0.2 \mathrm{M}$ potassium cacodylate, $0.25 \mathrm{mg} / \mathrm{ml} \mathrm{BSA}$, and $1.5 \mathrm{~mm} \mathrm{CoCl} 2$ for $15 \mathrm{~min}$ at $37^{\circ} \mathrm{C}$ and purified by ethanol precipitation. The tail length was 10-15 nucleotides as determined by PAGE.

For in situ hybridization histochemistry, the tissue was fixed by transcardial perfusion with $4 \%$ paraformaldehyde (4 animals with bilateral FFT and two unoperated controls). Cryostat sections of $20 \mu \mathrm{m}$ (coronal plane of the septal region and horizontal plane of the hippocampus) were prepared and mounted on silanized glass slides. Permeabilization of the tissue included $\mathrm{HCl}$ and proteinase $\mathrm{K}$ treatment. Brain sections were then prehybridized with hybridization buffer at $42^{\circ} \mathrm{C}$ for $2-3 \mathrm{hr}$. The hybridization solution contained $20 \%$ formamide, $4 \times$ SSC $(1 \times$ SSC $=0.15 \mathrm{~m}$ $\mathrm{NaCl}$ and $0.015 \mathrm{~m}$ sodium citrate, $\mathrm{pH} 7.0), 50 \mathrm{~mm}$ Tris/ $\mathrm{HCl}, \mathrm{pH} 7.0,5 \mathrm{~mm}$ EDTA, $1 \%$ SDS, $5 \times$ Denhardt's solution, $0.1 \mathrm{mg} / \mathrm{ml}$ sonicated denatured salmon sperm DNA, $0.1 \mathrm{mg} / \mathrm{ml}$ tRNA, and $10 \%$ dextransulfate. This solution was drained and replaced with the hybridization mixture, which was the same but included $10,000 \mathrm{cpm} / \mu \mathrm{l}$ radiolabeled oligonucleotide probe. Sections were covered with parafilm and incubated in a moist chamber at $42^{\circ} \mathrm{C}$ overnight. The sections were washed three times for 15 min in a buffer containing $1 \times \mathrm{SSC}, 0.1 \% \mathrm{SDS}$ at $42^{\circ} \mathrm{C}$. Thereafter, a more stringent wash with $0.2 \times \mathrm{SSC}, 0.1 \%$ SDS was performed twice for $15 \mathrm{~min}$ at RT. Slices were dehydrated through graded ethanols containing $0.3 \mathrm{M}$ ammonium acetate, coated with Kodak NTB-2 photo emulsion, and 
exposed at $4^{\circ} \mathrm{C}$ for 3 weeks. They were developed in Kodak D19 developer and fixed in $24 \%$ sodium thiosulfate. As a last step, the sections were counterstained with cresyl violet, dehydrated, and mounted in DePeX (Gurr, BDH Chemicals, Poole, UK).

Northern blot analysis. Immunostaining for c-fos was supplemented by a Northern blot analysis for c-fos mRNA, which was carried out as described by Haas et al. (1993). In brief, unoperated $(n=2)$ and fimbria-fornix-transected ( 2 and $7 \mathrm{~d}, n=2$ each) rats were killed by decapitation, the brains were frozen on dry ice, and the medial septal nuclci were microdissected with a sterile razor blade. Cytoplasmic RNA of the septal area was prepared from each animal individually and size-fractionated by agarose gel electrophoresis as described. As a positive control for c-fos mRNA expression, RNA extracted from PC12 cells [treated with nerve growth factor (NGF) for $30 \mathrm{~min}$ ] was used. Northern transfer was performed by vacuum blotting on Hybond $\mathrm{N}$ nylon membrane with $20 \times$ SSC. A c-fos cDNA probe was radiolabeled by random priming with $\left[\alpha_{-}^{-32} \mathrm{P}\right] \mathrm{dCTP}(3000 \mathrm{Ci} / \mathrm{mmol}$; DuPont NEN). Hybridization and washing conditions were the same as described previously (Haas et al., 1993).

\section{RESULTS}

\section{Control of FFT by AChE histochemistry and ChAT immunostaining}

To assess the completeness of the FFT, sections of hippocampus were processed for AChE histochemistry. The loss of AChEpositive fiber staining in the hippocampus has been used widely as a control for the complete transection of septohippocampal fibers (Naumann et al., 1994). AChE staining was performed at all studied time points from $6 \mathrm{~d}$ onward except at early stages ( 1 and $2 \mathrm{~d}$ postlesion), because the degeneration of $\mathrm{AChE}$-positive fibers in the hippocampus requires $\sim 1$ week. In the deafferented hippocampi, there was a dramatic loss of AChE-positive fibers when compared with unoperated controls, which show a dense fiber network stained by AChE histochemistry. ChAT-IR was examined in unoperated control animals and at time points from $1 \mathrm{~d}$ up to 9 weeks in axotomized neurons of the MS. In line with previous reports (references cited in the introductory remarks), there was a dramatic loss of ChAT-IR neurons as early as $6 \mathrm{~d}$ postlesion (Fig. 1a,b).

\section{Analysis of DNA fragmentation}

The TUNEL technique designed to detect DNA fragmentation was applied to sections of the medial septal nucleus at the following postoperative time intervals: $1,2,6,7,8,12$, and $21 \mathrm{~d}$. No nuclear labeling was observed in the septal region, indicating the absence of DNA fragmentation at the time points studied (Fig. 1c). In DNase I-treated control sections of the MS, however, a clear nuclear staining was observed (Fig. 1d).

To monitor the sensitivity of the TUNEL procedure applied in this study, another control experiment was performed. Wholemounts of newborn rat retinae were examined for apoptotic retinal ganglion cells (RGCs), which undergo naturally occurring cell death at this stage of development (Cunningham, 1982). Numerous nuclei of RGCs were labeled in this experiment, indicating the high sensitivity of our procedure (data not shown).

\section{Expression of immediate early genes in response to FFT}

In unoperated control animals, no IR was observed for c-jun (Fig. $2 a$ ), jun B, and c-fos. After FFT we noticed a selective and long-lasting increase in immunostaining for c-jun in MSDB neurons (Fig. 2). No immunolabeling for $\mathrm{c}$-fos and jun $\mathrm{B}$ was found in lesioned rats. In line with the immunocytochemical findings, no c-fos mRNA was detected in the MSDB by Northern blot analysis of unoperated or axotomized animals (Fig. 3).

Many c-jun-IR neuronal nuclei were observed in the MS as early as $2 \mathrm{~d}$ postaxotomy. In our time course analysis, the number of c-jun-positive neurons was highest at $6 \mathrm{~d}$ postlesion (Fig. $2 b$ ), followed by a decline around postlesional day 12 (Fig. 2c). After 3 weeks, the population of c-jun-positive MS neurons dropped remarkably. No c-jun-positive neurons were found after a survival period of 9 weeks (Fig. $2 d$ ).

To confirm that an increase in c-jun-IR in axotomized medial septal neurons was accompanied by enhanced mRNA synthesis, in situ hybridization histochemistry was used. ${ }^{33} \mathrm{P}$-labeled oligonucleotide probes specific for c-jun mRNA applied to tissue sections of the MS revealed a strong increase of c-jun mRNA in this brain region (Fig. 4a,b). Dense clusters of silver grains were concentrated over the MS and diagonal band of Broca. An accumulation of silver grains over Nissl-counterstained MS neurons indicated enhanced c-jun gene expression compared with that in unoperated controls (Fig. 4c). As in our immunocytochemical preparations with c-jun antibodies, the c-jun mRNA increase was restricted to the MSDB. The lateral septum that does not project to the hippocampus was spared. No hybridization was observed with sense controls.

Although it is well established that most septohippocampal neurons project to the hippocampus via the fimbria fornix and therefore are axotomized by FFT (Jacab and Leranth, 1995), an attempt was made in the present study to identify c-jun-positive septohippocampal projection neurons by retrograde labeling with FG before axotomy. This tracer was shown in previous studies to be a reliable marker for septohippocampal projection neurons that stays in the cell bodies for extended periods of time after tracer injection into the hippocampus (Naumann et al., 1992a).

In these double-labeling studies, unilateral fimbrial lesions were performed. We observed a heavy c-jun immunolabeling of medial septal neurons on the lesioned side, which suggests that $c$-jun immunostaining is causally related to the lesion. The few c-junpositive cells on the contralateral side most likely belong to the crossed septohippocampal projection (Peterson, 1989), which was also transected in these experiments. Many double-labeled neurons were observed in the MS, suggesting that immunostaining for c-jun was induced by axotomy (Fig. 5).

In the double-stained sections (Fig. $5 a-c$ ), the heavily c-junlabeled nuclei of septohippocampal neurons stood out against the less intensely FG-labeled cytoplasm of those cells. In contrast, solely FG-stained neurons displayed a pale nucleus surrounded by a halo of FG immunolabeling (Fig. 5c). The c-jun-positive neuronal population was always FG-labeled, but not all FG-stained cells were c-jun-positive (Fig. $5 b$ ). In control animals that were only retrogradely labeled with $\mathrm{FG}$, intense nuclear staining was absent (Fig. 5d).

\section{DISCUSSION}

In the present study, we have shown that injured septohippocampal neurons selectively express c-jun mRNA and protein in a long-term manner, but not $c$-fos or jun $B$. In addition, we have demonstrated that these axotomized central neurons do not exhibit DNA fragmentation.

Previous studies have suggested that medial septal neurons degenerate and die after axotomy by transection of the fimbriafornix. Thus, Daitz and Powell (1954) and McLardy (1955a,b) observed a loss of large neurons in the MS in Nissl stain and concluded that these cells degenerate as a result of axotomy. In line with these early observations, many investigators found a dramatic loss of ChAT-IR neurons in the MS after FFT (Gage et al., 1986, 1988; Hefti, 1986; Williams et al., 1986; Armstrong et al., 

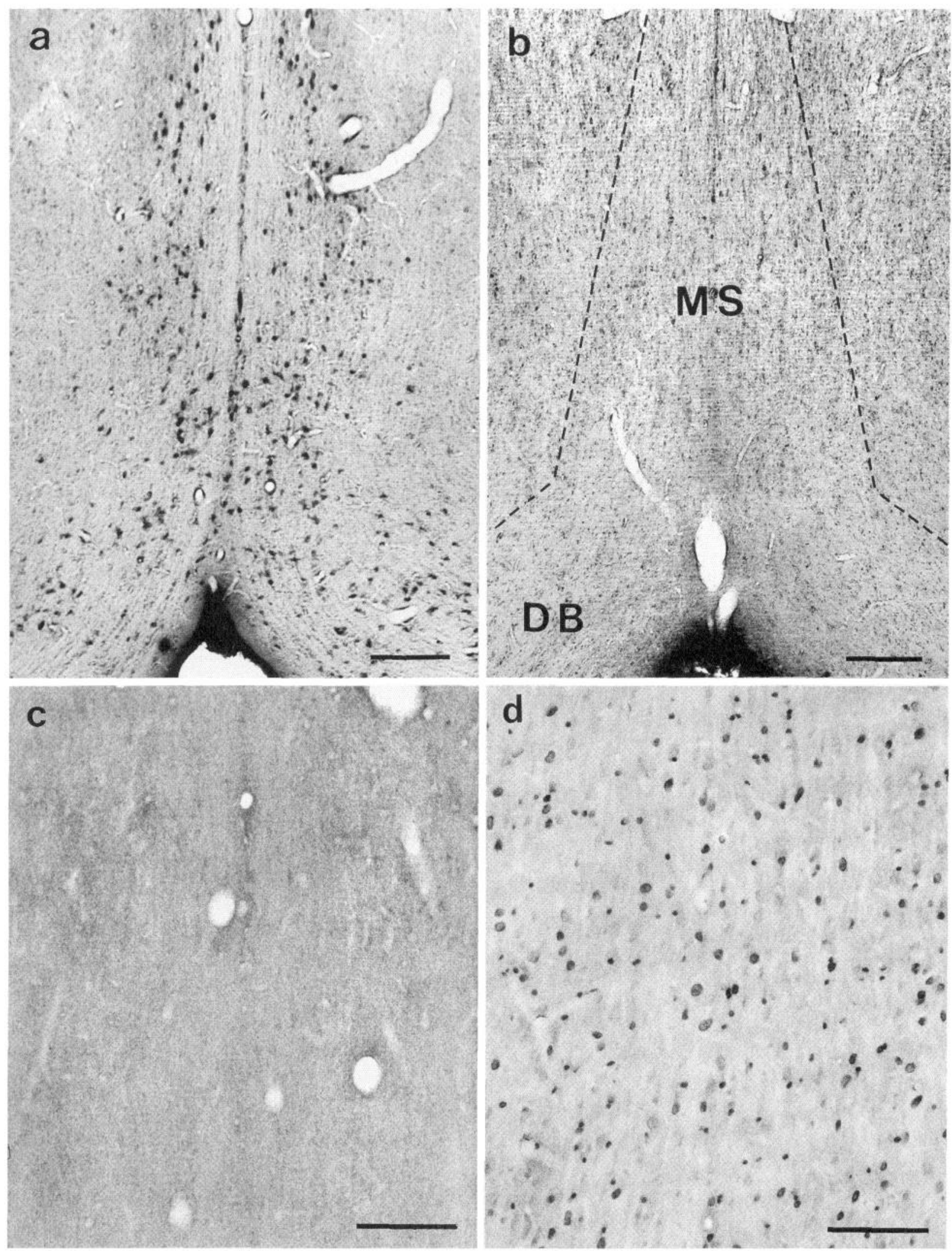

Figure 1. ChAT immunostaining and in situ labeling of DNA fragmentation (TUNEL) in sections of the MSDB. $a, b$, ChAT immunostaining in the MSDB. $a$, Unoperated control animal. Many ChAT-IR neurons are present in the MS and diagonal band of Broca. $b$, Six days after FFT. Loss of ChAT immunostaining in the $M S D B$. Scale bar, $200 \mu \mathrm{m} . c, d$, TUNEL analysis in the MSDB. $c$, Three weeks after FFT. No DNA fragmentation is detected in the MSDB after this as well as after other survival periods. $d$, DNase I treatment resulted in the labeling of many MSDB nuclei. $M S$, Medial septum; $D B$, diagonal band of Broca. Scale bar, $100 \mu \mathrm{m}$. 

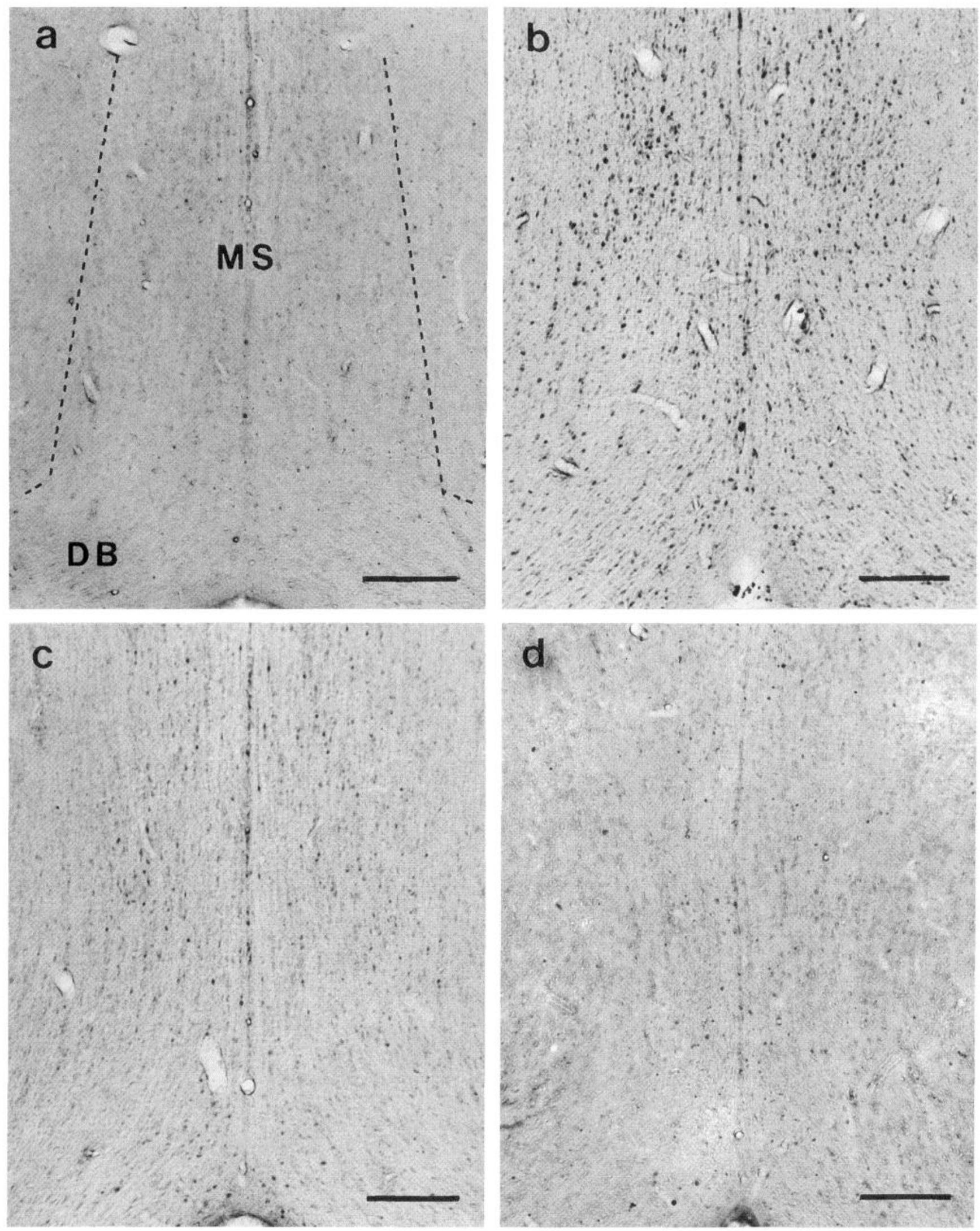

Figure 2. c-jun immunostaining in the MS after various survival times following FFT. $a$, In an unoperated control animal, only background staining is seen. $b$, Six days after lesion, many c-jun-positive nuclei are seen in the MSDB. $c$, Twelve days after FFT, the number of $c$-jun-positive nuclei has decreased when compared with $6 \mathrm{~d}$ postlesion. $d$, Nine weeks after FFT, c-jun-positive nuclei have disappeared. $M S$, Medial septum; $D B$, diagonal band of Broca. Scale bars, $200 \mu \mathrm{m}$. 


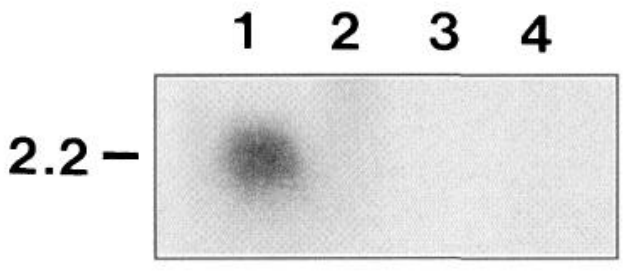

Figure 3. Northern blot analysis of c-fos mRNA expression in the septal area after FFT. The autoradiogram of one representative experiment is shown. Only the positive control (NGF-treated PC12 cells) gives a hybridization signal. c-fos mRNA is not found in septal RNA from either unoperated or operated animals. Lane 1, PC12 cells treated with NGF for 30 min. Lane 2, Septal nucleus of unoperated animal. Lane 3, Septal nucleus $2 \mathrm{~d}$ after FFT. Lane 4, Septal nucleus $7 \mathrm{~d}$ after FFT. RNA sizes are given in kilobases.

1987; Kromer, 1987; Frotscher, 1988; Naumann et al., 1992b); however, prelabeling of septohippocampal neurons with retrograde tracer before axotomy and intracellular staining of the prelabeled and then axotomized neurons revealed survival of many septohippocampal projection cells after fimbria-fornix lesion (Frotscher and Naumann, 1992; Naumann et al., 1992b; Peterson et al., 1992).

Intracellular staining of prelabeled and axotomized cells proved the survival of individual neurons, but may not be the adequate method for monitoring the extent of degeneration or cell death occurring in the entire population of axotomized neurons. Recent studies have provided evidence that the TUNEL technique labels not only apoptotic cells but also degenerating neurons (Berkelaar et al., 1994; Rabacchi et al., 1994; Nitatori et al., 1995). In line with our previous reports on axotomized and then intracellularly stained neurons, our present results with the TUNEL technique do not provide evidence for a massive degeneration of septohippocampal projection neurons after axotomy. Nuclear DNA fragmentation could not be detected in any of the postlesional stages analyzed. We have reason to assume that the applied procedure is highly sensitive, because we were able to monitor apoptotic cell death in the developing retina as well as DNA fragmentation by DNase treatment. Nevertheless, we cannot ignore the fact that some degeneration has occurred in the present experiments, which may have escaped the analysis of the present postlesional stages. In fact, previous studies have indicated that DNA fragmentation is a rapid process (Johnson and Deckwerth, 1993). It should be pointed out, however, that our electron microscopic studies analyzing the time course of retrograde neuronal changes after axotomy did not reveal clumping of nuclei in axotomized septohippocampal neurons (Frotscher and Naumann, 1992; Naumann et al., 1992b). In summary, we conclude that there is no massive retrograde cell death in the MS after FFT.

In agreement with the lack of degeneration in the TUNEL experiments, we found an increased IR for the immediate early gene c-jun in the axotomized cells. This induction of c-jun-IR was selective, because no similar immunostaining was observed with antibodies against c-fos and jun B protein. Moreover, no c-fos mRNA was detected by Northern blot analysis in the septal complex after FFT. This lack of c-fos expression is in agreement with other studies of axotomized neurons (Jones and Evinger, 1991; Dragunow, 1992; Herdegen et al., 1992; Haas et al., 1993). The increased immunostaining for c-jun was accompanied by an enhanced c-jun mRNA expression. We have reason to assume that the expression of $\mathrm{c}$-jun in septal neurons is causally related to the axotomy of these cells, because IR was found only in identified (FG-prelabeled) septohippocampal projection neurons and was restricted to the MSDB. Also, in the double-labeling experiments, which were performed only unilaterally, the c-jun immunolabeling was found almost exclusively on the lesioned side. The completeness of the FFT was proven by AChE staining of the hippocampus. Only rats devoid of AChE-positive fibers in the hippocampus and fascia dentata were included in the present study.

The selective immunostaining for c-jun in axotomized medial septal neurons raises the question of the functional significance of this immediate early gene in the present experimental paradigm. Recent in vitro studies have shown that c-jun is necessary for neuronal apoptosis in NGF-dependent sympathetic neurons during development (Estus et al., 1994; Ham et al., 1995). However, c-jun is also expressed in regenerating and sprouting neurons of adult animals after peripheral nerve transection (Jenkins and Hunt, 1991; Leah et al., 1991; Herdegen et al., 1992; Haas et al., 1993; Jenkins et al., 1993a). It is tempting to speculate that the increased IR for c-jun observed in the present study is related to neuronal survival rather than cell death, because no obvious signs of degeneration were found (see above). In fact, the septohippocampal neurons not only may survive axotomy but may have the capacity to regenerate and reinnervate their appropriate target tissue (Cadelli and Schwab, 1991; Linke et al., 1995).

What could be the function of c-jun in the axotomized neurons? c-jun is one member of a family of closely related proteins (including jun $\mathrm{B}$ and c-fos) that possess a leucine zipper through which they form hetero- or homodimers that will bind to the AP-1 DNA consensus element in target genes (Chiu et al., 1988; Nakebeppu et al., 1988; Cohen et al., 1989). In fact, c-jun can also homodimerize with itself to activate transcription (Karin and Smeal, 1992), and this is possibly the case in axotomized MSDB neurons, which do express c-jun but not c-fos and jun B. A possible target for $\mathrm{c}$-jun action could be the ChAT gene that contains an AP-1 site in its promoter (Hahn et al., 1992) and is inducible by AP-1 proteins in vitro (Bausero et al., 1993). We hypothesize a downregulation of ChAT expression by c-jun in axotomized medial septal neurons. As mentioned, there is a massive loss of ChAT-IR cells after FFT paralleled by an increase in c-jun. Moreover, IR for c-jun ceases after 3 weeks postlesion, whereas ChAT-IR recovers in axotomized septohippocampal neurons with increasing survival time (Naumann et al., 1994).

The molecular mechanisms that lead to c-jun induction are still unknown. Block of axonal transport by colchicine mimics the effect of axotomy and causes c-jun induction (Leah et al., 1991, 1993). This indicates that disconnection from target-derived factors activates c-jun expression. In the septohippocampal system, it is known that the target cells in the hippocampus produce NGF and brain-derived neurotrophic factor (BDNF) and their mRNAs (Korsching et al., 1985; Ayer-LeLievre et al., 1988; Ernfors et al., 1990; Hofer et al., 1990; Phillips et al., 1990; Wetmore et al., 1991). NGF and BDNF are retrogradely transported from the hippocampus to the parent cell bodies in the MS (Schwab et al., 1979; Seiler and Schwab, 1984; DiStefano et al., 1992). One may speculate that FFT disconnects MSDB neurons from their growth factor supply, and in turn this could cause c-jun expression. Evidence against a growth factor-dependent regulation of c-jun in 



Figure 4. Localization of c-jun mRNA in the MSDB by in situ hybridization histochemistry with ${ }^{33}$ P-radiolabeled oligonucleotides. $a$, Dark-field photograph of unoperated animal. Only background levels of silver grains are detected over the tissue section. $b$, Dark-field photograph $6 \mathrm{~d}$ after FFT. Note the strong accumulation of silver grains over the MSDB, indicating increased c-jun mRNA levels in these areas. $M S$, Medial septum; $D B$, diagonal band of Broca; $L S$, lateral septum; $L V$, lateral ventricle. Scale bars, $1,000 \mu \mathrm{m}$. $c$, Bright-field photograph of medial septal neurons shown in $b$ at higher magnification. Neurons that display a strong hybridization signal for c-jun mRNA are indicated by arrows. Tissue was counterstained with cresyl violet. Scale bar, $60 \mu \mathrm{m}$. 

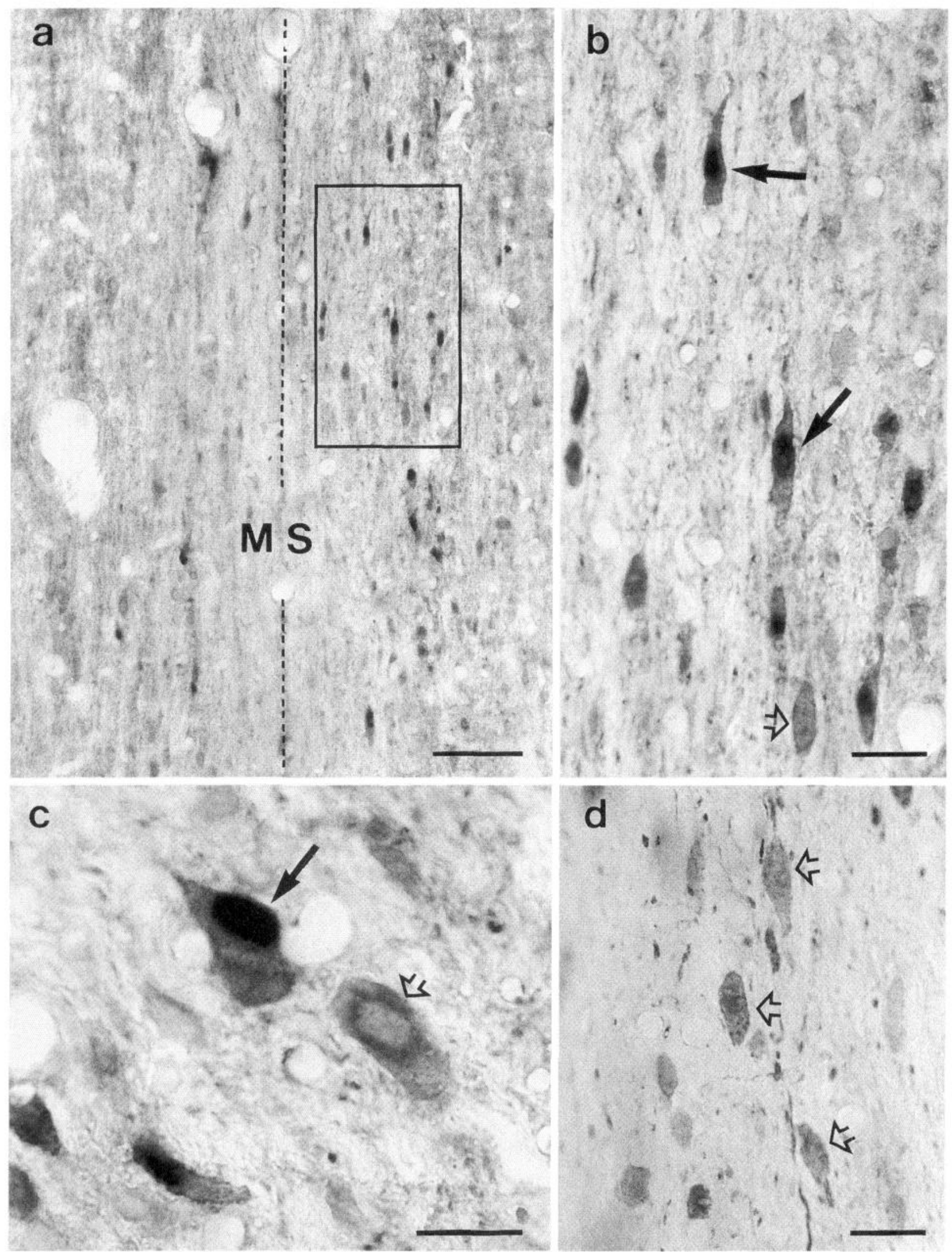

Figure 5. Colocalization of the retrograde tracer FG and c-jun IR in axotomized neurons of the MSDB. $a$, Medial septal nucleus (MS) after unilateral retrograde tracing with FG followed by ipsilateral FFT (survival time, $6 \mathrm{~d}$ ). Framed area is shown at higher magnification in $b$. Scale bar, $200 \mu \mathrm{m}$. $b$, Framed area in $a$ at higher magnification. Arrows indicate double-labeled neurons with cytoplasmic FG IR and nuclear, Ni/Co-enhanced c-jun labeling. Open arrow points to a neuron that is only FG-labeled. Scale bar, $50 \mu \mathrm{m}$. $c$, High magnification of c-jun/FG double-labeled neuron (arrow) and an FG-positive cell (open arrow). Scale bar, $40 \mu \mathrm{m}$. $d$, Single immunostaining for FG. Note absence of intense nuclear staining. Scale bar, $50 \mu \mathrm{m}$. 
neurons comes from in vitro studies on dorsal root ganglion cells, however, where the addition of NGF or BDNF did not inhibit the expression of c-jun (DeFelipe and Hunt, 1994). In these sensory neurons, c-jun expression is obviously not related to neurotrophin deprivation; a suppressing effect of other growth factors, however, cannot be excluded. The results of the present study do not allow one to draw conclusions as to the mode of c-jun induction. They do point to a possible involvement of c-jun in neuronal survival and regeneration, however, whereas the two other transcription factors studied here, jun B and c-fos, do not seem to play a role.

\section{REFERENCES}

Amaral DG, Kurz J (1985) An analysis of the origins of the cholinergic and noncholinergic septal projections to the hippocampal formation of the rat. J Comp Neurol 240:37-59.

Angel P, Allegretto EA, Okino ST, Hattori K, Boyle WJ, Hunter T, Karin M (1988) Oncogene jun encodes a sequence-specific trans-activator similar to AP-1. Nature 332:166-171.

Armstrong DM, Terry RD, Deteresa RM, Bruce G, Hersh LB, Gage F (1987) Response of septal cholinergic neurons to axotomy. J Comp Neurol 264:421-436.

Ayer-LeLievre C, Olson L, Ebendal T, Seiger A, Persson H (1988) Expression of $\beta$-nerve growth factor gene in hippocampal neurons. Science 240:1339-1341.

Bausero P, Schmitt M, Toussaint JL, Simoni P, Geoffroy V, Queuche D Duclaud S, Kempf J, Quirin-Stricker C (1993) Identification and analysis of the human choline acetyltransferase gene promoter. NeuroReport 4:287-290.

Berkelaar M, Clarke DB, Wang Y-C, Bray GM, Aguayo AJ (1994) Axotomy results in delayed death and apoptosis of retinal ganglion cells in adult rats. J Neurosci 14:4368-4374.

Bialowas J, Frotscher M (1987) Choline acetyltransferase-immunoreactive neurons and terminals in the rat septal complex: a combined light and electron microscopic study. J Comp Neurol 259:298-307.

Brecht S, Martin-Villalba A, Zuschratter W, Bravo R, Herdegen T (1995) Transection of rat fimbria-fornix induces lasting expression of c-Jun protein in axotomized septal neurons immunonegative for choline acetyltransferase and nitric oxide synthase. Exp Neurol 134:112-125.

Cadelli D, Schwab ME (1991) Regeneration of lesioned septohippocampal acelylcholinesterase-positive axons is improved by antibodies against the myelin-associated neurite growth inhibitors NI-35/250. Eur J Neurosci 3:825-832.

Chiu R, Boyle WJ, Meek J, Smeal T, Hunter T, Karin M (1988) The c-fos protein interacts with $\mathrm{c}$-jun/AP-1 to stimulate the transcription of AP-1 responsive genes. Cell 54:541-552.

Cohen DR, Ferreira PCP, Gentz R, Franza Jr BR, Curran T (1989) The product of a fos-related gene, fra-1, binds cooperatively to the AP-1 site with Jun: transcription factor AP-1 is comprised of multiple protein complexes. Genes Dev 3:173-184.

Cunningham TJ (1982) Naturally occurring neuron death and its regulation by developing neural pathways. Int Rev Cytol 74:163-186.

Daitz HM, Powell TPS (1954) Studies of the connexions of the fornix system. J Neurol Neurosurg Psychiatry 17:75-82.

DeFelipe C, Hunt SP (1994) The differential control of c-jun expression in regenerating sensory neurons and their associated glial cells. $J$ Neurosci 14:2911-2923.

DiStefano PS, Friedman B, Radziejewsky C, Alexander C, Boland P, Schick CM, Lindsay RM, Wiegand SJ (1992) The neurotrophins BDNF, NT3 and NGF display distinct patterns of retrograde axon transport in peripheral and central neurons. Neuron 5:511-526.

Dragunow M (1992) Axotomized medial septal-diagonal band neurons express jun-like immunoreactivity. Mol Brain Res 15:141-144.

Ernfors P, Wetmore C, Olson L, Persson H (1990) Identification of cells in rat brain and peripheral tissues expressing mRNA for members of the nerve growth factor family. Neuron 5:511-526.

Estus S, Zaks WJ, Freeman RS, Gruda M, Bravo R, Johnson Jr EM (1994) Altered gene expression in neurons during programmed cell death: identification of $c-j u n$ as necessary for neuronal apoptosis. $\mathbf{J}$ Cell Biol 127:1717-1727.

Freund TF, Antal M (1988) GABA-containing neurons in the septum control inhibitory interneurons in the hippocampus. Nature 336:170-173.
Frotscher M (1988) Cholinergic neurons in the rat hippocampus do not compensate for the loss of septohippocampal cholinergic fibers. Neurosci Lett 87:18-22.

Frotscher M, Naumann T (1992) Septohippocampal cholinergic neurons: synaptic connections and survival following axotomy. Rev Neurosci 3:233-248.

Gage FH, Wictorin W, Fischer W, Williams LR, Varon S, Björklund A (1986) Retrograde cell changes in medial septum and diagonal band following fimbria-fornix transection: quantitative temporal analysis. Neuroscience 19:241-255.

Gage FH, Armstrong DM, Williams LR, Varon S (1988) Morphological response of axotomized septal neurons to nerve growth factor. J Comp Neurol 269:147-155.

Gage FH, Tuszynski MH, Chen KS, Armstrong D, Buzsaki G (1989) Survival, growth and function of damaged cholinergic neurons. In: Central cholinergic synaptic transmission (Frotscher M, Misgeld U, eds), pp 259-274. Berlin: Birkhäuser.

Gavrieli Y, Sherman Y, Ben-Sasson SA (1992) Identification of programmed cell death in situ via specific labeling of nuclear DNA fragmentation. J Cell Biol 119:493-501.

Haas CA, Donath C, Kreutzberg GW (1993) Differential expression of immediate early genes after transection of the facial nerve. Neuroscience 53:91-99.

Hahn M, Hahn SL, Stone DE, Joh TH (1992) Cloning of the rat gene encoding choline acetyltransferase, a cholinergic neuron-specific marker. Proc Natl Acad Sci USA 89:4387-4391.

Ham J, Babij C, Whitfield J, Pfarr CM, Lallemand D, Yaniv M, Rubin LL (1995) A c-jun dominant negative mutant protects sympathetic neurons against programmed cell death. Neuron 14:927-939.

Hefti F (1986) Nerve growth factor promotes survival of septal cholinergic neurons after fimbrial transections. J Neurosci 6:2155-2162.

I Ierdegen T, Fiallos-[strada CE, Schmid W, Bravo R, Zimmermann M (1992) The transcription factors c-JUN, JUN D and CREB, but not FOS and KROX-24, are differentially regulated in axotomized neurons following transection of rat sciatic nerve. Mol Brain Res 14:155-165.

Herdegen T, Bastmeyer M, Bähr M, Stürmer CAO, Bravo R, Zimmermann M (1993) Expression of JUN, KROX and CREB transcription factors in goldfish and rat retinal ganglion cells following optic nerve lesions is related to axonal sprouting. J Neurobiol 24:528-543.

Hofer M, Pagliusi SR, Hohn A, I eibrock I, Barde Y-A (1990) Regional distribution of brain-derived neurotrophic factor mRNA in the adult mouse brain. EMBO J 9:2459-2464.

Houser CR, Crawford GD, Barber RP, Salvaterra PM, Vaughn JE (1983) Organization and morphological characteristics of cholinergic neurons: an immunocytochemical study with a monoclonal antibody to choline acetyltransferase. Brain Res 266:97-119.

Hüll M, Bähr M (1994a) Differential regulation of c-JUN expression in rat retinal ganglion cells after proximal and distal optic nerve transection. Neurosci Lett 178:39-42.

Hüll M, Bähr M (1994b) Regulation of immediate-early gene expression in rat retinal ganglion cells after axotomy and during regeneration through a peripheral nerve graft. J Neurobiol 25:92-105.

Jacab RL, Leranth C (1995) Septum. In: The rat nervous system (Paxinos G, ed), pp 405-431. San Diego: Academic.

Jenkins R, Hunt SP (1991) Long-term increase in the levels of c-jun mRNA and Jun protein-like immunoreactivity in motor and sensory neurons following axon damage. Neurosci Letl 129:107-110.

Jenkins R, McMahon SB, Bond AB, Hunt SP (1993a) Expression of c-jun as a response to dorsal root and peripheral nerve section in damaged and adjacent intact primary sensory neurons in the rat. Eur $\mathrm{J}$ Neurosci 5:751-759.

Jenkins R, Tetzlaff W, Hunt SP (1993b) Differential expression of immediate early genes in rubrospinal neurons following axotomy in rat. Eur J Neurosci 5:203-209.

Johnson Jr EM, Deckwerth TL (1993) Molecular mechanisms of developmental neuronal death. Annu Rev Neurosci 16:31-46.

Jones KJ, Evinger C (1991) Differential neuronal expression of c-fos proto-oncogene following periphcral nerve injury or chemically-induced seizure. J Neurosci Res 28:291-298.

Karin M, Smeal T (1992) Control of transcription factors by signal transduction pathways: the beginning of the end. Trends Biochem Sci 17:418-422.

Köhler C, Chan-Palay V, Wu JY (1984) Septal neurons containing glutamic acid decarboxylase immunoreactivity project to the hippocampal region in the rat brain. Anat Embryol (Berl) 169:41-44. 
Koistinaho J, Hicks KJ, Sagar SM (1993) Long-term induction of c-jun mRNA and Jun protein in rabbit retinal ganglion cells following axotomy or colchicine treatment. J Neurosci Res 34:250-255.

Korsching S, Auburger G, Heumann R, Scott J, Thoenen H (1985) Levels of nerve growth factor and its mRNA in the central nervous system of the rat correlate with cholinergic innervation. EMBO J 4:1389-1393.

Kromer LF (1987) Nerve growth factor treatment after brain injury prevents neuronal death. Science 235:214-216.

Leah JD, Ilerdegen T, Bravo R (1991) Sclcctive cxpression of Jun proteins following axotomy and axonal block in peripheral nerves in the rat: evidence for a role in the regeneration process. Brain Res 566:198-207.

Leah JD, Herdegen T, Murashov A, Dragunow M, Bravo R (1993) Expression of immediate early gene proteins following axotomy and inhibition of axonal transport in the rat central nervous system. Neuroscience 57:53-66.

Lewis PR, Shute CCD (1967) The cholinergic limbic system: projections to hippocampal formation, medial cortex, nuclei of the ascending cholinergic reticular system and the subfornical organ and supraoptic crest. Brain 90:521-540.

Linke R, Heimrich B, Frotscher M (1995) Axonal regeneration of identified septohippocampal projection neurons in vitro. Neuroscience 68:1-4.

McLardy T (1955a) Observations on the fornix of the monkey. I. Cell studies. J Comp Neurol 103:305-326.

McLardy T (1955b) Observations on the fornix of the monkey. II. Fiber studies. J Comp Neurol 103:327-344.

Mesulam M-M, Geula C, Moran MA (1987) Anatomy of cholinesterase inhibition in Alzheimer's disease: effect of physostigmine and tetrahydroaminoacridine on plaques and tangles. Ann Neurol 22:683-691.

Morgan JI, Curran T (1991) Stimulus-transcription coupling in the nervous system: involvement of the inducible proto-oncogenes fos and jun. Annu Rev Neurosci 14:421-451.

Nakebeppu Y, Ryder K, Nathans D (1988) DNA binding activities of three murine Jun proteins: stimulation by Fos. Cell 55:907-915.

Naumann T, Linke R, Frotscher M (1992a) Fine structure of rat septohippocampal neurons: identification of septohippocampal projection neurons by retrograde tracing combined with electron microscopic immunocytochemistry and intracellular staining. J Comp Neurol 325:207-218.

Naumann T, Peterson GM, Frotscher M (1992b) Fine structure of rat septohippocampal neurons. II. A time course analysis following axotomy. J Comp Neurol 325:219-242.

Naumann T, Kermer P, Frotscher M (1994) Fine structure of rat septohippocampal neurons. III. Recovery of choline acetyltransferase immunoreactivity after fimbria-fornix transection. J Comp Neurol 350:161-170.
Nitatori T, Sato N, Waguri S, Karasawa Y, Araki H, Shibanai K, Kominami E, Uchiyama $Y(1995)$ Delayed neuronal death in the pyramidal cell layer of the gerbil hippocampus following transient ischemia is apoptosis. J Neurosci 15:1001-1011.

Peterson GM (1989) A quantitative analysis of the crossed septohippocampal projection in the rat brain. Anat Embryol (Berl) 180:421-425.

Peterson GM, Williams LR, Varon S, Gage FH (1987) Loss of GABAergic neurons in medial septum after fimbria-fornix transection. Neurosci Lett 776:140-144.

Pctcrson GM, Lanford GW, Powcll EW (1990) Fatc of scptohippocampal neurons following fimbria-fornix transection: a time course analysis. Brain Res Bull 25:129-137.

Peterson GM, Naumann T, Frotscher M (1992) Identified septohippocampal neurons survive axotomy: a fine-structural analysis in the rat. Neurosci Lett 138:81-85.

Phillips HS, Hains JM, Laramee GR, Rosenthal A, Winslow JW (1990) Widespread expression of BDNF but not NT3 by target areas of basal forebrain cholinergic neurons. Science 250:290-294.

Plaschke M, Kasper EM, Naumann T, Frotscher M (1994) Survival and transmitter expression of rat cholinergic medial septal neurons despite removal of hippocampus in the early postnatal period. Neurosci Lett 176:243-246.

Rabacchi SA, Bonfanti L, Liu X-H, Maffei L (1994) Apoptotic cell death induced by optic nerve lesion in the neonatal rat. J Neurosci 14:5292-5301.

Schwab ME, Otten U, Agid Y, Thoenen H (1979) Nerve growth factor (NGF) in the rat CNS: absence of specific retrograde axonal transport and tyrosine hydroxylase induction in locus coeruleus and substantia nigra. Brain Res 168:473-483.

Seiler M, Schwab ME (1984) Specific retrograde transport of nerve growth factor (NGF) from neocortex to nucleus basalis in the rat. Brain Res 300:33-39.

Sheng M, Greenberg M (1990) The regulation and function of c-fos and other immediate early genes in the nervous system. Neuron 4:477-485.

Sofroniew MV, Galletly NP, Isacson O, Svendsen CN (1990) Survival of adult basal forebrain cholinergic neurons after loss of target neurons. Science 247:338-342.

Sofroniew MV, Cooper JD, Svendsen CN, Crossman P, Ip NY, Lindsay RM, Zafra F, Lindholm D (1993) Atrophy but not death of adult septal cholinergic neurons after ablation of target capacity to produce mRNAs for NGF, BDNF and NT3. J Neurosci 13:5263-5276.

Wetmore C, Cao Y, Petterson RF, Olson L (1991) Brain-derived neurotrophic factor: sub-cellular compartmentalization and interneuronal transfer as visualized with anti-peptide antibodies. Proc Natl Acad Sci USA 88:9843-9847.

Williams LR, Varon S, Peterson GM, Wictorin K, Fischer W, Björklund A, Gage FH (1986) Continuous infusion of nerve growth factor prevents basal forebrain neuronal death after fimbria fornix transection. Proc Natl Acad Sci USA 83:9231-9235. 